\title{
The Impact of Market Discipline on Banks' Capital Adequacy: Evidence From an Emerging Economy
}

\section{Ayesha Afzal*}

\begin{abstract}
This study presents empirical support for the role of market discipline in augmenting bank capital ratios in a competitive banking environment. Using a panel dataset on domestic commercial banks in Pakistan from 2009 to 2014, the study determines if the market penalized banks for any increase in their risk profile through a rise in the cost of raising funds. The results point to a significant relationship between capital adequacy and other risk factors, with the cost of deposits demonstrating how depositors align the required return to the perceived risk level of the bank. These findings have important implications for policymakers as market discipline could complement the role of regulators, which would eventually lower the cost of supervision. Moreover, the focus of international reforms as seen through the implementation of Basel III should continue to be on developing a more competitive and transparent banking system.
\end{abstract}

Keywords: Basel norms, capital adequacy ratio, market discipline.

JEL classification: G210, G280.

\section{Introduction}

The Basel Accord of 1988 introduced capital requirements as a formal part of banking regulations. Recurring financial crises - through the realization of various risks faced by the financial sector - have had a grave impact on the world economy and thus justified the need for regulation. The problems caused by bank failure have increased in severity with the development of financial markets and products: the excessive rise in on-balance and off-balance sheet (OBS) leverage operating under the shadow banking system, coupled with insufficient liquidity and eroding capital, were among the major causes of the 2007 global financial crisis. Moreover, the increased interconnectedness of financial institutions through a stream of highly integrated and complex transactions has augmented the systemic risk of the sector. Any failure in

\footnotetext{
* Assistant Professor, Lahore School of Economics.
} 
the banking sector diffuses swiftly into the rest of the financial system with unprecedented losses to the real economy.

Keeping in mind this susceptibility of the financial sector and its negative consequences, Basel II (2004) and Basel III (2009) emphasize solvency and soundness within the banking system by requiring an increase in the level and quality of capital held by banks. By ensuring minimum capital requirements and prescribed capital adequacy ratios (CARs), among other things, the regulations aim to rationalize banks' risk-taking behavior.

The role of regulators was supplemented by the introduction of the disciplinary role of related stakeholders vis-à-vis depositors, shareholders, and bondholders. Basel II introduced Pillar III - the concept of market discipline as an important part of bank regulation, the objective of which is to promote "transparency" by publicly disseminating all information relevant to risks and returns. For this purpose, banks are required to ensure the online availability of their financial statements with comprehensive disclosure of banking risks for the benefit of analysis by investors.

Related stakeholders are, therefore, expected to assess the bank's risk level based on the "disclosed" information when aligning their preferences. In situations where there are high levels of risk, they may require higher compensation (in terms of the risk premium) or, better yet, diversify their selection. Consequently, market discipline by private agents involves two different features. The first is the aptitude of depositors and investors for observing and identifying any changes in the bank's risk profile; the second is their authority in influencing the actions of bank management by requiring higher returns (Goday, Gruss, \& Ponce, 2005; Flannery, 2001). Genschel and Plümper (1997) support the argument by showing that the Basel capital adequacy standards have led to greater transparency, enabling markets to reward or penalize banks based on their risk levels.

The introduction of market discipline to supplement capital requirements could help ensure a sounder banking system by penalizing banks with lower levels of capitalization. With the market discipline mechanism in order, these banks are expected to compensate depositors by paying them a higher risk premium. This would increase the cost of raising funds and, therefore, lead banks to moderate their risk appetite.

In a scenario where the banking sector is highly competitive, market discipline can reinforce capital regulation. It can motivate banks 
to sustain a resilient capital base to safeguard them from potential future losses arising as a result of risk exposures. This could lead banks to maintain their capital ratios as prescribed by the central bank, resulting in the lower cost of bank supervision as market participants complement government regulation. This view is supported by Dowd (2000) who confirms that shareholders can act to ensure that bank behavior enforces appropriate levels of risk.

The basic motivation for imposing a regulated CAR is based on the premise that banks prefer to maintain a lower level of capital than what is optimal for a sound and solvent banking system (Dewatripont \& Tirole, 1993). Banks face the opportunity cost of holding capital in terms of lower profitability, especially when operating in a relatively competitive market, and thus prefer to remain undercapitalized. In the presence of a regulatory capital ratio, the same opportunity cost of foregone profits would compel banks to practice minimal compliance with the standard proposed (Avery \& Berger, 1991; Chishty, 2011). This implies that the presence of a regulated CAR would ensure the convergence of capital ratios around the level proposed by the regulator.

To allow market discipline to effectively impinge on any imprudent behavior on the part of banks and force changes in the cost of raising funds, the financial regime has to be competitive. When the banking system is highly concentrated, banks tend to collude on the rates offered to depositors and borrowers. In such a situation, depositors are unable to penalize banks with lower levels of capitalization. Also, in the absence of competition, the potential threat of deposit switching is mitigated, leaving banks free to make independent financing decisions.

In a liberalized financial regime and in the presence of regulatory capital requirements, competing banks are likely to maintain higher-thanrequired CARs. In such a case, banks can achieve a higher CAR by raising their levels of capital or reducing their lending (Basel Committee on Banking Supervision, 1999). The CAR is the ratio of Tier 1 and Tier 2 capital to risk-weighted assets (RWA). If the higher CAR is being achieved by a reduction in RWA, this could lead to the rationing of bank credit, which in turn might marginalize some sectors of the economy. SME, agriculture, and housing, for instance, are potential contributors to GDP growth in developing countries.

However, banks operating under a liberalized financial regime are seen to be unwilling to lend to these sectors due to the higher level of 
associated risks and transaction costs. Such measures may have a negative effect on the growth and prosperity of the real economy. In a developing economy such as Pakistan, which faces many crises in the real sectors ranging from low supplies of energy to political unrest - cutting back on advances may be more profitable for banks relative to raising new capital.

The objective of this study is to evaluate the level of CAR among banks operating in Pakistan. It also provides evidence of the existence of market discipline in explaining deviations in the CAR from the regulated level. Section 2 details the sample selection and methodology, followed by a discussion of the findings in Section 3. The paper concludes and provides a set of policy implications in Section 4.

\section{Methodology}

To determine if the presence of market discipline affects the CAR level maintained by banks in Pakistan, this study takes a sample of 27 domestic commercial banks (listed public limited companies) and analyzes their financial statements. We use balanced panel data for various bank-specific variables to obtain an equal number of crosssectional observations for each of the six years from 2009 to 2014. The study estimates two models for this purpose.

\subsection{Model 1}

In the theory of finance, the relationship between risk taken and return earned is definite and direct. In the presence of market discipline, depositors are likely to rationalize the risk-taking behavior of undercapitalized banks by asking for a higher return on the funds lent, thereby increasing the cost of deposits for the bank. Hence, the dependent variable is defined as the ratio of the interest cost of capital (IE) to the bank's interest-bearing liabilities (IntLiab):

$$
c_{i t}=\left(\frac{I E_{i t}}{\text { IntLiab }}\right)_{i t} \text { for bank } i \text { at time } t \text {. }
$$

The independent variables are the CAR, asset quality, return on equity, the size of the bank, and fee-based income.

$$
c_{i t}=\alpha_{i}+\beta_{1} C A R_{i t}+\beta_{2}\left(N P L_{i t} / G L_{i t}\right)+\beta_{3} R O E_{i t}+\beta_{4} L O G\left(T A_{i t}\right)+\beta_{5}\left(O B S_{i t} / T A_{i t}\right)+\varepsilon_{i t}
$$


The variable CAR is a measure of the capital buffer against contingent losses. Banks with a higher CAR are less vulnerable to shocks and considered less risky. In the presence of market discipline, the market will reward banks with a higher capital buffer by enabling a lower cost of funds.

Asset quality is measured as the ratio of nonperforming loans (NPLs) to gross loans. A high ratio would indicate poor asset quality and be deemed riskier. Banks with a large share of NPLs on their balance sheets are likely to experience a higher cost of deposits. Return on equity is a measure of the bank's profitability. The market should reward a higher ratio by lowering the funding cost. This would encourage the bank management to make efficient portfolio decisions both for lending and investment.

Taking the log of total assets (TA) measures the size of the bank and is used as a control variable to mitigate variations in bank size across the sample. Larger banks experience economies of scale and scope compared to smaller banks, putting the latter at a clear disadvantage. Therefore, this variable is critical to control for these variations.

Banks in Pakistan earn most of their fee-based income through trade-related instruments such as letters of credit. The OBS-to-TA ratio measures such earned income. Banks with a higher ratio are perceived to have a lower level of risk because they have this avenue as an alternative revenue form and will probably experience a low cost of funds. Table 1 gives the variables and their expected signs.

Table 1: Expected signs (model 1)

\begin{tabular}{llc}
\hline & \multicolumn{1}{c}{ Variable } & Expected sign \\
\cline { 2 - 3 } Cost of deposits $\left(c_{i t}\right)$ & Capital adequacy & - \\
& Impaired lending to gross advances & + \\
& OBS/TA & - \\
& Return on equity & - \\
& Size (control variable) & - \\
\hline
\end{tabular}

\subsection{Model 2}

Taking the premise that a competitive banking industry encourages banks to maintain a higher capital buffer relative to their peers to ensure a steady, low-cost source of funds, we estimate the following equation:

$$
c_{i t}=\alpha_{i}+\beta_{1}\left(C A R_{i t}-C A R i n d\right)+\beta_{2}\left(N P L_{i t} / G L_{i t}\right)+\beta_{3} R O E_{i t}+\beta_{4} L O G\left(T A_{i t}\right)+\beta_{5}\left(O B S_{i t} / T A_{i t}\right)+\varepsilon_{i t}
$$


Such measures, if taken by all financial intermediaries, would reduce the systemic risk of the banking system as a whole and lower borrowing costs for all banks (Ghosh \& Das, 2003). In this model, the deviation in the CAR of each bank in the sample is taken from the industry to show the effect of this externality on the borrowing cost faced by the bank. All other variables remain the same. Table 2 lists the variables and their expected signs.

Table 2: Expected signs (model 2)

\begin{tabular}{llc}
\hline & \multicolumn{1}{c}{ Variable } & Expected sign \\
\cline { 2 - 3 } CAR bank - CAR industry & - \\
Cost of deposits $\left(c_{i t}\right)$ & Impaired lending to gross advances & + \\
& OBS/TA & - \\
& Return on equity & - \\
& Size (control variable) & - \\
\hline
\end{tabular}

\section{Findings and Discussion}

Figure 1 shows the level of CAR held by banks in Pakistan for three years, 2009, 2011, and 2014. The State Bank of Pakistan has imposed a minimum CAR of 10 percent as prescribed by Basel II for all banks operating in the country.

Figure 1: CAR for banks in Pakistan

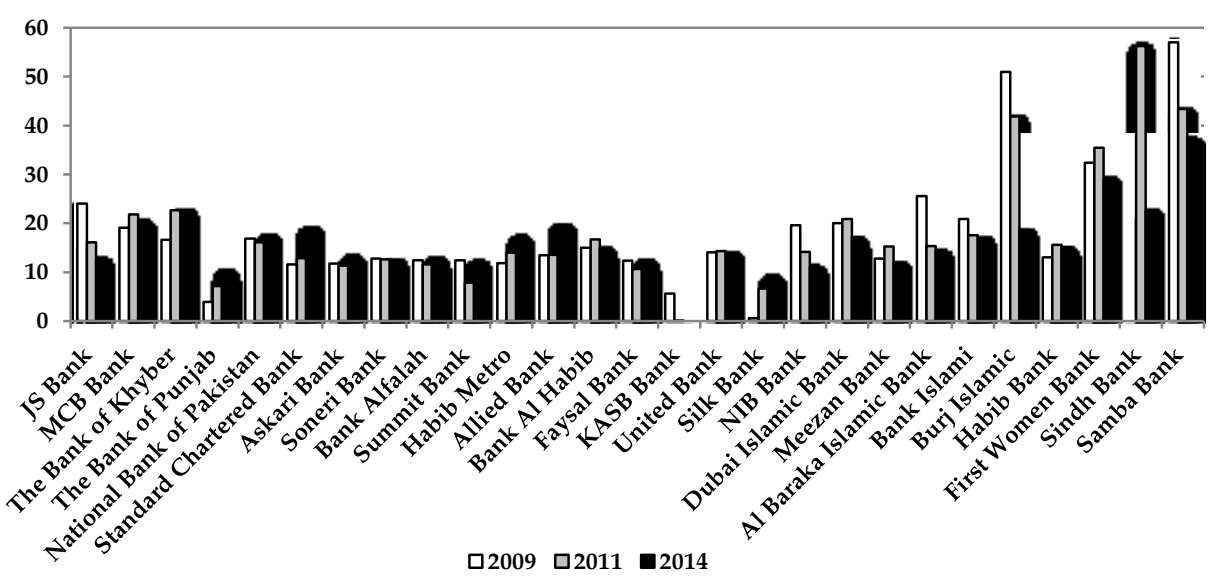

Source: Author's calculations.

Ninety percent of the banks in this sample have a CAR well above the prescribed level of 10 percent. This observation contradicts the earlier premise that banks' CAR levels will converge onto the regulated level for 
all participants. It is possible that banks hold a higher level of regulatory capital (RC) because the increased transparency of financial information has enhanced the ability of market participants to exert pressure on banks to maintain higher capital buffers by imposing a penalty on the cost of raising funds.

This view supports Ghosh and Das (2003), who suggest that capital regulation influences bank behavior and, therefore, should be designed in a way to encourage banks to maintain higher-than-regulatory ratios so as to reflect on their differing levels of risks. The ability of financial markets to penalize undercapitalized banks would lead to all banks operating in a competitive banking structure to maintain a high level of capital in order to enjoy a lower funding cost.

To determine if the banking system structure in Pakistan is competitive enough to allow market discipline to be effective, we estimate the Herfindahl-Hirschman index (HHI). This measures the extent to which market output is concentrated among banks. Table 3 gives the HHI for bank deposits and loans for 2009-14.

Table 3: HHI estimates, 2009-14

\begin{tabular}{ccc}
\hline Year & Deposits & Loans/advances \\
\hline 2009 & $9.123 \%$ & $8.993 \%$ \\
2010 & $8.859 \%$ & $9.043 \%$ \\
2011 & $8.408 \%$ & $8.195 \%$ \\
2012 & $8.321 \%$ & $8.150 \%$ \\
2013 & $8.481 \%$ & $8.704 \%$ \\
2014 & $8.363 \%$ & $8.031 \%$ \\
\hline
\end{tabular}

Source: Author's calculations.

We observe an HHI of 8.363 percent for 2014, which is indicative of a competitive market. Moreover, as seen in Table 3, this index follows a declining trend, representing the transition to a highly competitive market as a result of banking sector deregulation liberalization. This is confirmed by looking at the decrease in the share of the top five banks according to market share in the total loans and deposits of the banking sector. Where, in 2009, these banks accounted for 59 percent of total deposits and 60 percent of total loans, their share falls to 55 percent and 53 percent, respectively, by 2014.

Banks in Pakistan maintain a high level of capitalization relative to regulatory requirements. It is, therefore, imperative to check whether 
this leads to reduced lending by banks. Table 4 presents the changes in RWA and RC along with the cumulative changes observed in the CAR for the 27 observed commercial banks; this is according to the format suggested by the Basel Committee on Banking Supervision (1999).

The relative changes we see reflect that banks have not reduced their lending; rather, they have generally increased both their RWA and level of RC over the years. This finding supports the ability of market forces to exert pressure on banks to hold a level of RC that is higher than the regulatory requirement.

Table 4: Comparison of RC and RWA, 2009-13

\begin{tabular}{|c|c|c|c|c|c|c|c|c|c|c|c|c|c|c|c|}
\hline \multirow[b]{2}{*}{ Bank } & \multicolumn{3}{|c|}{2009} & \multicolumn{3}{|c|}{2010} & \multicolumn{3}{|c|}{2011} & \multicolumn{3}{|c|}{2012} & \multicolumn{3}{|c|}{2013} \\
\hline & $\underset{\simeq}{U}$ & $\sum_{\mathbb{1}}^{\mathbb{Z}}$ & 芩 & $\underset{\simeq}{U}$ & $\underset{\nwarrow}{\nwarrow}$ & 光 & $\underset{\simeq}{\cup}$ & 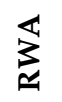 & $\underset{u}{u}$ & $\underset{\simeq}{\cup}$ & 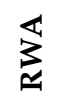 & $\underset{u}{\sharp}$ & $\underset{\simeq}{\cup}$ & 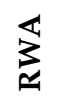 & 苻 \\
\hline JS Bank & + & + & - & - & + & - & + & + & - & + & + & + & - & + & + \\
\hline $\mathrm{MCB}$ & + & + & + & + & - & + & + & + & - & + & + & + & + & + & + \\
\hline Bank of Khyber & + & + & - & + & - & + & + & + & + & + & + & + & + & + & - \\
\hline Bank of Punjab & + & - & + & - & - & - & + & + & + & + & + & + & + & + & + \\
\hline National Bank of Pakistan & + & + & + & + & + & + & + & + & - & + & + & - & + & + & - \\
\hline Standard Chartered Bank & + & + & + & + & + & + & + & + & + & + & - & + & + & + & + \\
\hline Askari Bank & + & + & + & - & + & - & + & + & + & + & + & + & - & + & - \\
\hline Soneri Bank & + & + & + & + & + & - & + & + & + & + & + & - & + & + & - \\
\hline Bank Alfalah & - & - & + & + & + & - & + & + & + & + & + & + & + & + & - \\
\hline Summit Bank & - & + & - & - & + & - & + & + & + & - & - & - & + & + & + \\
\hline Habib Metro & + & + & + & + & + & - & + & - & + & + & - & + & + & + & - \\
\hline Allied Bank & + & + & + & + & + & + & + & + & - & + & - & + & + & + & + \\
\hline Bank Al Habib & + & + & + & + & + & - & + & - & + & + & + & - & + & + & - \\
\hline Faysal Bank & + & - & + & + & + & - & + & + & + & + & + & + & + & - & + \\
\hline KASB Bank & - & - & - & - & - & - & - & + & - & - & + & - & + & - & + \\
\hline United Bank & + & + & + & - & + & + & + & - & - & + & + & + & + & + & - \\
\hline Silkbank & - & + & - & + & + & + & + & + & + & - & + & - & + & + & + \\
\hline NIB Bank & + & + & + & - & - & - & - & - & - & - & + & - & - & + & - \\
\hline Dubai Islamic Bank & + & + & - & + & - & + & + & + & - & + & + & - & + & + & - \\
\hline Meezan Bank & + & + & + & + & + & + & - & + & + & + & + & - & + & + & - \\
\hline Al Baraka Islamic Bank & - & + & - & + & + & - & + & + & + & - & + & - & + & + & + \\
\hline Bank Islami & - & + & - & + & + & - & + & + & - & + & + & - & + & + & + \\
\hline Burj Islamic & + & + & + & - & + & - & + & + & + & - & + & - & - & - & - \\
\hline Habib Bank & + & + & + & - & - & - & + & + & + & + & + & - & + & + & - \\
\hline First Women Bank & + & - & + & + & + & - & + & + & + & + & + & - & - & - & - \\
\hline Sindh Bank & na & na & na & na & na & na & 0 & 0 & 0 & + & + & - & - & + & - \\
\hline Samba Bank & + & + & + & - & + & - & + & + & - & + & + & + & + & + & - \\
\hline
\end{tabular}

Source: Author's calculations. 
Given a competitive banking structure, our hypothesis seems even more plausible: we argue that banks maintain a higher level of CAR to retain their source and reduced cost of funding in the presence of market discipline. Table 5 presents the empirical results for model 1.

The coefficient of CAR is negative and significant at 95 percent, indicating that banks with higher levels of capitalization are rewarded by the market in the form of a lower interest cost of deposits. This is evidence of the presence of market discipline in Pakistan's banking system. A study conducted on US bank holding companies by Keeley (1990) reports similar findings: when the banks' capital ratio was raised by 1 percent, the result was a lowered rate on their certificate of deposits of 14 basis points.

\section{Table 5: Regression results (model 1)}

Dependent variable: interest expense/interest-bearing liability

\begin{tabular}{lrrrrr}
\hline & Coefficient & \multicolumn{1}{c}{ SE } & t-ratio & P-value & \\
\hline const & 0.000258772 & 0.000210927 & 1.2268 & 0.2217 & \\
CAR & -0.0291416 & 0.0142502 & -2.0450 & 0.0425 & $* *$ \\
NPLTL & 0.00491011 & 0.0026025 & 1.8867 & 0.0611 & $*$ \\
ROE & -0.00899349 & 0.003942 & -2.2815 & 0.0239 & $*$ \\
SIZElnTA & 0.00566647 & 0.00768006 & 0.7378 & 0.4617 & \\
OBSTA & $6.72364 \mathrm{e}-05$ & 0.000716717 & 0.0938 & 0.9254 & \\
& & & & & \\
R-squared & 0.57893 & & & \\
Adj. R-squared & 0.27698 & & & \\
P-value (F) & 0.00414 & & & & \\
\hline
\end{tabular}

Note: ${ }^{*}$ significance at $90 \%,{ }^{* *}$ significance at $95 \%,{ }^{* * *}$ significance at $99 \%$.

Source: Author's calculations.

This result is augmented by the positive and significant coefficient of asset quality. Banks with a poor-quality loan portfolio are penalized by the market in the shape of a higher cost of funding through interest-bearing liabilities. Yeyati, Peria, and Schmukler's (2004) study of similar emerging economies finds evidence from systemic bank runs in Argentina and Uruguay during 2000-02 that depositors do penalize banks in the face of higher systemic risks arising from bank fundamentals such as NPLs.

The result for return on equity is negative and significant, providing further evidence that the market assigns great weight to banks' performance. A higher return on equity indicates the managerial 
efficiency and good quality of the bank's asset portfolio, encouraging depositors to lend funds to the bank at a lower rate of return.

The regression results of model 2, as shown in Table 6, confirm the existence of market discipline in Pakistan. The variable carcarind has a highly significant and negative coefficient. This shows that a competitive banking system does lead banks to maintain a high level of capitalization: an increase in the CAR of one bank relative to the industry reduces its cost of borrowing. Ghosh and Das (2003) report similar findings for the Indian banking sector where a rise in the industry's CAR reduces the individual bank's borrowing costs. Moreover, banks have to maintain a lower delinquency ratio to ensure a continuous flow of funds at a lower cost (as can be seen from the coefficient of NPLs to total loans). The result is consistent with that of model 1.

\section{Table 6: Regression results (model 2)}

Dependent variable: interest expense/interest-bearing liability

\begin{tabular}{|c|c|c|c|c|c|}
\hline & Coefficient & SE & t-ratio & P-value & \\
\hline const & 0.00578756 & 0.00768752 & 0.7529 & 0.4527 & \\
\hline carcarind & -0.00895532 & 0.00393223 & -2.2774 & 0.0241 & ** \\
\hline NPLTL & 0.0324214 & 0.0134881 & 2.4037 & 0.0174 & ** \\
\hline $\mathrm{ROE}$ & 0.000264192 & 0.000209989 & 1.2581 & 0.2102 & \\
\hline SIZElnTA & -0.00498593 & 0.00260867 & -1.9113 & 0.0578 & * \\
\hline OBSTA & $6.54365 \mathrm{e}-05$ & 0.000716541 & 0.0913 & 0.9274 & \\
\hline R-squared & 0.058358 & & & & \\
\hline Adj. R-squared & 0.028177 & & & & \\
\hline P-value (F) & 0.091732 & & & & \\
\hline
\end{tabular}

Note: ${ }^{*}$ significance at $90 \%,{ }^{* *}$ significance at $95 \%,{ }^{* * *}$ significance at $99 \%$.

Source: Author's calculations.

Larger banks experience economies of scale and asset diversification with a wider outreach through a larger branch network this lowers their perceived riskiness. As a result, the coefficient of size is negative and significant, showing that smaller banks have to offer higher returns to attract depositors.

\section{Conclusion}

This study finds evidence to support the presence of market discipline in the banking system of Pakistan and confirms its effect on the level of bank capitalization. This finding is consistent with evidence of 
market discipline in other emerging economies, such as Chile (Budnevich \& Franken, 2003), Argentina (Calomiris \& Powell, 2001), Colombia (Barajas \& Steiner, 2000), and India (Ghosh \& Das, 2003).

Banks with a higher CAR are rewarded by the market in the form of a lower cost of raising funds. Market forces also moderate their risk-taking behavior: when depositors are conscious of any idiosyncratic risk, they will penalize the bank by demanding a higher return on their deposits. Furthermore, competition among banks has led to an increase in the CAR across the industry to a level that exceeds the regulatory requirement.

This indicates that market forces have strengthened the supervisory role of the State Bank of Pakistan as banks are encouraged to maintain a higher level of capital buffers. This is likely to augment the role of supervision and reduce its associated costs. By maintaining a higher level of capital buffers, banks contribute to the stability and solvency of the banking system as a whole, and push risky banks to become better capitalized or exit the market. This conclusion is supported by Nier's (2004) cross-country analysis, which reveals that the increased transparency of banks reduces their vulnerability to financial crises. 


\section{References}

Avery, R. B., \& Berger, A. N. (1991). Risk-based capital and deposit insurance reform. Journal of Banking and Finance, 15(4-5), 847-874.

Barajas, A., \& Steiner, R. (2000). Depositor behavior and market discipline in Colombia (Working Paper No. 00/214). Washington, DC: International Monetary Fund.

Basel Committee on Banking Supervision. (1999). Capital requirements and bank behavior: The impact of the Basel Accord (Working Paper No. 1). Basel: Bank for International Settlements.

Budnevich, C., \& Franken, H. (2003). Disciplina de mercado en la conducta de los depositantes y rol de las agencias calsificadoras de riesgo: El caso de Chile. Economia Chilena, 6(2), 45-70.

Calomiris, C., \& Powell, A. (2001). Can emerging market bank regulators establish credible discipline? The case of Argentina 1992-1999. In F. S. Mishkin (Ed.), Prudential supervision: What works and what doesn't. Cambridge, MA: National Bureau of Economic Research.

Chishty, K. A. (2011). The impact of capital adequacy requirements on profitability of private banks in India: A case study of J\&K, ICICI, HDFC and Yes Bank. International Journal of Research in Commerce and Management, 2(7), 122-129.

Dewatripont, M., \& Tirole, J. (1993). Efficient governance structure: Implications for banking regulation. In C. Mayer \& X. Vives (Eds.), Capital markets and financial intermediation (chap. 2). Cambridge: Cambridge University Press.

Dowd, K. (2000). Bank capital adequacy versus deposit insurance. Journal of Financial Services Research, 17(1), 7-15.

Flannery, M. J. (2001). The faces of "market discipline". Journal of Financial Services Research, 20(2), 107-119.

Genschel, P., \& Plümper, T. (1997). Regulatory competition and international cooperation. Journal of European Public Policy, 4, 626-642. 
Ghosh, S., \& Das, A. (2003). Market discipline in the Indian banking sector: An empirical exploration (Paper No. 82). Mumbai: NSE Research Initiative.

Goday, V., Gruss, B., \& Ponce, J. (2005). Depositors' discipline in Uruguayan banks (Documento de Trabajo 003). Montevideo: Banco Central del Uruguay.

Keeley, M. C. (1990). Deposit insurance, risk, and market power in banking. American Economic Review, 80(5), 1183-1200.

Nier, E. (2004). Bank stability and transparency. Financial Stability Review, $17,112-118$.

Yeyati, E. L., Peria, M., \& Schmukler, S. (2004). Market discipline under systemic risk: Evidence from bank runs in emerging economies (Policy Research Working Paper No. 3440). Washington, DC: World Bank. 